\title{
An Insight into the Institutional Structure and Legal Framework to Implement the Nagoya Protocol on Access and Benefit Sharing (ABS)
}

\author{
M. Sangeetha ${ }^{1 *}$,M. Gaddi Gangappa ${ }^{1}$ and Ramachandra Bhatta ${ }^{2}$ \\ ${ }^{1}$ Dept. of Agricultural Economics, University of Agricultural Sciences, Bangalore, India \\ ${ }^{2}$ Former ICAR Emeritus Scientist, Mangalore, India \\ *Corresponding author
}

\section{Keywords}

Nagoya protocol, Access and benefit sharing, Bioresources

\section{Article Info}

Accepted:

16 November 2020

Available Online:

10 December 2020

\section{A B S T R A C T}

Biodiversity is the variability of all life forms including the flora and fauna species, which provide potential human benefits. Genetic resources and species are unevenly distributed over the planet. Nagoya Protocol on Access to Genetic Resources and the Fair and Equitable Sharing of Benefits Arising from their Utilization to the Convention on Biological Diversity was adopted on 29 October 2010, in Nagoya, Japan and came into force from 12 October 2014. The present investigation on comparative study of institutional structure and legal framework of four selected countries viz. India, Mexico, Peru and South Africa possessing rich biodiversity and representing four continents was based on secondary data compiled from Nagoya Protocol and National Authority websites. The analysis of the reports of the sample countries revealed compliance with the obligations of the Nagoya Protocol by designating the National Focal Point (NFP) and Competent National Authority (CAN). Among the countries, India and South Africa have one CNA each, while Mexico (6) and Peru (4) with designated departments to provide more focused and better management of access and benefit sharing of the resources. India is the leading country with 1006 Internationally Recognized Certificate of Compliance with distantly followed South Africa with only 32 IRCCs. All sample countries have the unitary type of administrative set up to implement the protocol except India which has three tier structure with BMCs, State Biodiversity Board and National Biodiversity Authority. The parties under study have made use of their existing legislative provisions with amendments to implement the Nagoya protocol.

\section{Introduction}

Biodiversity is the variability of all life forms on earth including the flora and fauna species. Few places on earth are biologically rich as well as threatened. These resources provide potential human benefits and are crucial source of information to better understand the natural world. They are used to develop a wide range of products and services for human benefit. Genetic resources and species are unevenly distributed over the planet. Thus, the physical access to genetic resources needs to be facilitated and that the benefits obtained from their use must be shared equitably with the providers, this also 
includes valuable traditional knowledge associated with genetic resources. There is a need to create incentives to conserve biological diversity, sustainable use of its components, and enhance the contribution of biological diversity to sustainable development and human well-being. To address this the Nagoya Protocol on Access to Genetic Resources and the Fair and Equitable Sharing of Benefits Arising from their Utilization to the Convention on Biological Diversity was adopted at the tenth meeting of the Conference of the Parties on 29 October 2010, in Nagoya, Japan.

The Protocol entered into force on 12 October 2014. The objective of the Protocol is to provide appropriate access to genetic resources along with the fair and equitable sharing of the benefits arising from the utilization of genetic resources.

This study aims to understand the institutional structure, legislative, administrative and policy measures required to implement Nagoya Protocol by the countries.

\section{Materials and Methods}

An exploratory and descriptive research design was adopted for the study. Of the 124 countries that are party to the Nagoya Protocol of CBD, purposive sampling method was used to obtain a sample for the study. The countries with more biodiversity as detailed in Table 1 were considered for the sampling. These countries cover 10 per cent of the earth's surface but contain 70 per cent of the planet's biodiversity.

Among these countries, only 12 are parties to the Nagoya Protocol of CBD. They are Ecuador, Mexico, Peru, Venezuela, China, Indonesia, India, Philippines, Malaysia, Madagascar, Democratic Republic of Congo, and South Africa.
Based on the availability of the National Reports (NR) submitted to the ABS Clearing House and the number of IRCC the country possess, four countries were selected for the study. They were Mexico, South Africa, India and Peru, having representation of different continents.

The Biodiversity Index for these countries found to be very high ranging from 0.34 (Peru) to 0.52 (Mexico). The institutional structure, legislative and administrative framework of these countries were compared based on the secondary data collected from CBD and ABS Clearing House websites and official websites of National Authorities of the selected countries.

\section{Results and Discussion}

\section{Institutional structure}

To implement Nagoya Protocol, Parties have the key obligations contained in Articles 13 and 14 of the Protocol. Article 13 requires each Party to the Protocol to designate a National Focal Point (NFP), one or more Competent National Authorities (CNA) and to transmit their contact information to the Secretariat no later than the date of entry into force of the Protocol for the country.

Total of 174 National Focal Points were established, among them 121 are parties to Nagoya Protocol and are 53 non parties. Seventy countries have established Competent National Authorities with a total of 117 CNAs, as 13 countries have more than one CNA. Of these 70 countries, 65 are parties and 5 are non party countries.

Article 14 of the Nagoya Protocol requires Parties to make available to the ABS Clearing-House the following information.

Legislative, administrative and policy measures on access and benefit-sharing 
information on the national focal point and competent national authority or authorities

Permits or their equivalent issued at the time of access as evidence of the decision to grant Prior Informed Consent (PIC) and of the establishment of Mutually Agreed Terms (MAT).

All the sample countries chosen for the study, viz India, Mexico, Peru and South Africa have complied with the obligations of the Nagoya Protocol by designating the NFP and CAN. The details on the institutional structure of these countries are given in Table-1. India and South Africa have only one CNA each, which in accordance with applicable national legislative, administrative or policy measures is responsible for granting access, issuing written evidence that access requirements have been met and is responsible for advising on applicable procedures and requirements for obtaining prior informed consent and entering into mutually agreed terms. Mexico and Peru have six and four CNA, each designated to various departments which would provide more focused and better management of access and benefit sharing of the resources coming under their purview.

Compared to India, the number of permits or equivalent made available to the ABS Clearing House were less in other sample countries, this could be due to few negotiations made or the permits they were confidential.

Table.1 Countries with more biodiversity in the world

\begin{tabular}{|l|l|l|l|}
\hline America & Asia & Africa & Oceana \\
\hline Brazil & China & Madagascar & Australia \\
\hline Colombia & Indonesia & Democratic Republic of Congo & Papa New Guinea \\
\hline Ecuador & India & South Africa & \\
\hline Mexico & Philippines & & \\
\hline Peru & Malaysia & & \\
\hline Venezuela & & & \\
\hline United States & & & \\
\hline
\end{tabular}

Source: www.activesustainability.com

Table.2 Species diversity of the selected countries

\begin{tabular}{|l|c|c|c|c|c|c|c|}
\hline \multicolumn{1}{|c|}{ Country } & Birds & Amphibians & Reptiles & Fish & Mammals & $\begin{array}{c}\text { Vascular } \\
\text { plants }\end{array}$ & $\begin{array}{c}\text { BioD } \\
\text { Index }\end{array}$ \\
\hline Mexico & 1,104 & 396 & 957 & 2,624 & 523 & 26,071 & 0.52 \\
\hline South Africa & 762 & 132 & 447 & 2,087 & 297 & 23,420 & 0.50 \\
\hline India & 1,211 & 434 & 689 & 2,583 & 412 & 18,664 & 0.46 \\
\hline Peru & 1,858 & 572 & 495 & 1,573 & 467 & 17,144 & 0.34 \\
\hline
\end{tabular}

Source: Butler, 2019 
Table.3 Details of the institutional structure in the selected countries to comply with Nagoya Protocol

\begin{tabular}{|c|c|c|c|c|c|}
\hline Sl.no & Particulars & India & Mexico & Peru & South Africa \\
\hline 1 & Date of joining & $11^{\text {th }}$ May, 2011 & $24^{\text {th }}$ February, 2011 & $4^{\text {th }}$ May, 2011 & $11^{\text {th }}$ May, 2011 \\
\hline 2 & Date of ratification & $9^{\text {th }}$ October, 2012 & $16^{\text {th }}$ May, 2012 & $8^{\text {th }}$ July, 2014 & $10^{\text {th }}$ January, 2013. \\
\hline 3 & $\begin{array}{l}\text { National Focal } \\
\text { Point(NFP) }\end{array}$ & $\begin{array}{l}\text { The Ministry of } \\
\text { Environment Forests } \\
\text { and Climate Change } \\
\text { (MoEFCC) }\end{array}$ & $\begin{array}{l}\text { Primary Sector and } \\
\text { Renewable Natural } \\
\text { Resources of the Ministry } \\
\text { of the Environment and } \\
\text { Natural Resources } \\
\text { (SEMARNAT) }\end{array}$ & $\begin{array}{l}\text { General Directorate for } \\
\text { Biological Diversity, Vice } \\
\text { Ministry of Strategic } \\
\text { Development of Natural } \\
\text { Resources, Ministry of the } \\
\text { Environment }\end{array}$ & $\begin{array}{l}\text { National Department } \\
\text { of Environment, } \\
\text { Forestry and Fisheries }\end{array}$ \\
\hline 4 & $\begin{array}{l}\text { Competent National } \\
\text { Authority(CNA) }\end{array}$ & $\begin{array}{l}\text { National } \\
\text { Biodiversity } \\
\text { Authority (NBA) }\end{array}$ & $\begin{array}{l}\text { 1. Service National of } \\
\text { Inspection and } \\
\text { Certification of Seeds } \\
\text { (SNICS), Ministry of } \\
\text { Agriculture, Livestock, } \\
\text { Rural Development, } \\
\text { Fisheries and Food } \\
\text { (SAGARPA) } \\
\text { 2. General Directorate of } \\
\text { Wildlife, under } \\
\text { secretariat of } \\
\text { Management for } \\
\text { Environmental } \\
\text { Protection, Ministry of } \\
\text { Environment and } \\
\text { Natural Resources } \\
\text { (SEMARNAT). } \\
\text { 3. General Livestock } \\
\text { Coordination. } \\
\text { 4. General Directorate of } \\
\text { Forest and Soil } \\
\text { Management }\end{array}$ & $\begin{array}{l}\text { 1. Ministry of Agriculture } \\
\text { and Irrigation - } \\
\text { National Forest and } \\
\text { Wildlife Service } \\
\text { (MINAGRI-SERFOR) } \\
\text { 2. Ministry of Production } \\
\text { - Vice Ministry of } \\
\text { Fisheries and } \\
\text { Aquaculture. } \\
\text { 3. National Institute of } \\
\text { Agrarian Innovation. } \\
\text { 4. Directorate of } \\
\text { Inventions and New } \\
\text { Technologies (DIN) of } \\
\text { the National Institute } \\
\text { for Defense of } \\
\text { Competition and } \\
\text { Protection of } \\
\text { Intellectual Property } \\
\text { (INDECOPI) }\end{array}$ & $\begin{array}{l}\text { BABS Policy } \\
\text { Development and } \\
\text { Implementation, } \\
\text { Department of } \\
\text { Environmental } \\
\text { Affairs }\end{array}$ \\
\hline
\end{tabular}




\begin{tabular}{|c|c|c|c|c|c|}
\hline & & & $\begin{array}{l}\text { (DGGFyS). } \\
\text { 5. National Commission } \\
\text { for the Development of } \\
\text { Indigenous Peoples } \\
\text { (CDI). } \\
\text { 6. National Commission } \\
\text { for Protected Natural } \\
\text { Areas (CONANP) }\end{array}$ & & \\
\hline 5 & $\begin{array}{l}\text { Permits (or equivalent) } \\
\text { issued at the time of } \\
\text { access as evidence of the } \\
\text { decision to grant Prior } \\
\text { Informed Consent (PIC) } \\
\text { and of the establishment } \\
\text { of Mutually Agreed } \\
\text { Terms (MAT) }\end{array}$ & & & $\begin{array}{l}87 \text { non-commercial } \\
\text { permits. } \\
\text { Comprising of } 44 \text { granted } \\
\text { by SERFOR and } 43 \\
\text { granted by INIA. } \\
\text { [Until 2016] }\end{array}$ & $\begin{array}{l}105 \text { permits } \\
\text { However copies are } \\
\text { not available as they } \\
\text { are treated } \\
\text { confidential } \\
\text { [since } 2008 \text { ] }\end{array}$ \\
\hline 6 & $\begin{array}{l}\text { Internationally } \\
\text { recognized certificate of } \\
\text { compliance [IRCCs] }\end{array}$ & $\begin{array}{l}1006 \\
{\left[\text { As on } 1^{\text {st }} \text { July 2020] }\right.}\end{array}$ & $\begin{array}{l}8 \\
{\left[8^{\text {th }} \text { January 2019] }\right.}\end{array}$ & 16 & 32 \\
\hline 7 & Designated checkpoints & & & $\begin{array}{l}\text { 1. The Directorate of } \\
\text { Inventions and New } \\
\text { Technologies (DIN). } \\
\text { 2. The National } \\
\text { Commission for the } \\
\text { Protection of Access to } \\
\text { Peruvian Biological } \\
\text { Diversity and } \\
\text { Collective Knowledge } \\
\text { of Indigenous Peoples } \\
\text { (The National } \\
\text { Commission against } \\
\text { Biopiracy) (CNBio) } \\
\text { 3. CONCYTEC, }\end{array}$ & $\begin{array}{l}\text { 1. Patent office } \\
\text { 2. Ports of Entry \& } \\
\text { Exit } \\
\text { 3. Provincial Permit } \\
\text { Issuing Authorities } \\
\text { 4. National } \\
\text { Department of } \\
\text { Environmental } \\
\text { Affairs } \\
\text { [operational but not } \\
\text { yet formalized through } \\
\text { the ABS Clearing } \\
\text { House] }\end{array}$ \\
\hline
\end{tabular}




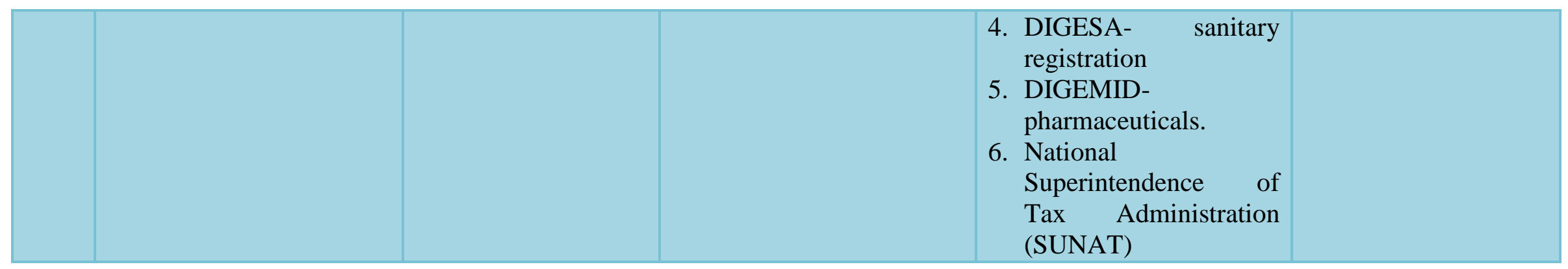

Table.4 Details of legislative, administrative and policy measures on ABS and their salient features in the selected countries to comply Nagoya Protocol

\begin{tabular}{|c|c|c|c|}
\hline Sl. No. & Country & Legal measure & Salient features \\
\hline 1 & India & $\begin{array}{l}\text { Biological Diversity Act in } 2002 \text { and notified the } \\
\text { Rules (Biological Diversity Rules) in } 2004\end{array}$ & $\begin{array}{l}\text { Implemented through 3-tier institutional mechanism: } \\
\text { At National: The National Biodiversity Authority (NBA) } \\
\text { At State level: State Biodiversity Boards (SBBs) and } \\
\text { At local level: The Biodiversity Management Committees } \\
\text { (BMCs) } \\
\text { Issued several notifications and guidelines on Access to } \\
\text { Biological Resources and Associated Knowledge and } \\
\text { Benefit Sharing Regulations, 2014, (referred to as ABS } \\
\text { Regulations, 2014) Prescribe the scheme of processing the } \\
\text { applications, along with template and terms for benefit } \\
\text { sharing. }\end{array}$ \\
\hline 2 & Mexico & $\begin{array}{l}\text { Issued the promulgatory decree, approved by the } \\
\text { Senate of the Republic. } \\
\text { Domestic operating legislations } \\
\text { The General Law of Ecological Balance and } \\
\text { Environmental Protection, } \\
\text { The General Law of Sustainable Forest } \\
\text { Development, } \\
\text { Law of Sustainable Rural Development, and }\end{array}$ & $\begin{array}{l}\text { For customer service, based on current legislation, } \\
\text { SAGARPA, through SNICS, defined an Internal } \\
\text { Transitional Procedure as an administrative mechanism to } \\
\text { deal with access requests. } \\
\text { In December 2014, the Government of Mexico, created the } \\
\text { Inter-Secretariat Group for the implementation of the } \\
\text { Nagoya Protocol and had defined the current access policy }\end{array}$ \\
\hline
\end{tabular}




\begin{tabular}{|c|c|c|c|}
\hline & & The General Law of Wildlife. & $\begin{array}{l}\text { in Mexico and agreed upon the procedures for dealing with } \\
\text { access permits/resolutions. } \\
\text { It is made up of } 22 \text { Federal Government Agencies. }\end{array}$ \\
\hline 3 & Peru & $\begin{array}{l}\text { Regulation of Access to Genetic Resources sets the } \\
\text { standard. It established the governing body - } \\
\text { MINAM for access to genetic resources. } \\
\text { Regime for the Protection of Collective Knowledge } \\
\text { of Indigenous Peoples Linked to Biological } \\
\text { Resources, in force since 2002, which establishes } \\
\text { Directorate of Inventions and New Technologies of } \\
\text { the National Institute for Defense of Competition and } \\
\text { Protection of Intellectual Property (DIN-INDECOPI) }\end{array}$ & $\begin{array}{l}\text { The Administration and Execution Authorities (AAE) are in } \\
\text { charge of attending to access requests, issuing resolutions } \\
\text { and verifying compliance with them, according to their } \\
\text { sectorial competence like } \\
\text { MINAGRI- for continental wild species, } \\
\text { INIA - for continental cultivated or domesticated species } \\
\text { VMPA-PRODUCE-for hydrobiological species. } \\
\text { SERNANP must issue a prior opinion binding on the } \\
\text { authorization of access to genetic resources from protected } \\
\text { natural areas. }\end{array}$ \\
\hline 4 & $\begin{array}{l}\text { South } \\
\text { Africa }\end{array}$ & $\begin{array}{l}\text { National Environmental Management: Biodiversity } \\
\text { Act, } 2004 \text { (NEMBA)- Chapter } 6 \text { - which includes } \\
\text { regulatory provisions on Bio-prospecting, Access and } \\
\text { Benefit Sharing and it came into force on } 1 \text { January } \\
\text { 2006is the framework legislation }\end{array}$ & $\begin{array}{l}\text { The legislation protects the interests of stakeholders, } \\
\text { outlines the requirements of material transfer and benefit } \\
\text { sharing agreements, establishes the Bio-prospecting Trust } \\
\text { Fund, and provides for the exemption of certain activities or } \\
\text { indigenous biological resources from the legislation. } \\
\text { It also provides for the management and conservation of its } \\
\text { biodiversity, the protection of species and ecosystem that } \\
\text { warrant national protection, the sustainable use of an } \\
\text { indigenous biological resource, the fair and equitable } \\
\text { sharing of benefits, the establishment and functions of a } \\
\text { South African National Biodiversity Institute. } \\
\text { Regulations on Bio-prospecting, Access and Benefit Sharing } \\
\text { (BABS Regulations) under the NEMBA entered into force } \\
\text { on } 1 \text { April } 2008 \text {. These Regulations have since been } \\
\text { amended and came into force on } 19 \text { May } 2015 \text {. }\end{array}$ \\
\hline
\end{tabular}


Legislative, administrative and policy structure

The details presented in Table- 2 on the various legislative measures prevalent or amended to their existing legislations to implement the protocol in the sample countries. It is very much clear from the table that except India, other countries have the unitary type of administrative set up to implement the protocol to extend benefits to the stakeholders and provide access to the resources. In India it is of three tier structure having BMCs at the grass root level, guided by the State Biodiversity Board for each state and all works under the guidance and support of National Biodiversity authority located at Chennai.

The parties under study have made used of their existing legislative provisions with minor modifications or amendments to implement the Nagoya Protocol.

In conclusion the key obligations contained in Articles 13 and 14 of Nagoya Protocol formed the base to establish an institutional structure for the implementation of the protocol. The parties under study have made use of their existing legislative provisions with minor modifications or amendments to implement the Nagoya Protocol. They have taken steps to operationalize the Nagoya Protocol but its implementation at the domestic level is yet to be effectively achieved. It is necessary to strengthen the institutional and human resource capacities at national, state and local levels to moderate access and benefit sharing and to accelerate its implementation. Check points could be identified and developed.

Having rich biodiversity, these countries form the source of valuable bio-resources and associated traditional knowledge. Hence, providing access through a transparent channel and sharing the benefits under this Protocol creates incentives to conserve biological diversity, sustainably use its components, and further enhance the contribution of biological diversity for the sustainable development and human well-being (Table 3 and 4).

The increasing evidence of the importance of natural capital means that countries cannot afford for biodiversity to be marginalized when it comes to national priorities. To elevate the status of biodiversity in local and national decision-making, its relevance for different communities must be clarified and ensure that the value and benefits are understood across the full spectrum of audiences. It is important to show how these benefits are aligned to countries developmental needs such as job creation, food security and the provision of basic services.

\section{References}

Anonymous, 2019, Nature's Dangerous Decline 'Unprecedented'; Species Extinction Rates 'Accelerating', United Nations Report

Butler, R. A., 2019, Countries with the highest biodiversity. Mongabay.com

Butler, R. A., 2016, The top 10 most biodiverse countries. Mongabay.com

Chaudary, E., Biodiversity Hotspots in the World, The Mighty Earth.com

Merritt, M., Maldaner, M. E. and Almeida, A. M. R., 2019, What Are Biodiversity Hotspots? Frontiers for Young Minds, 7-29.

www.activesustainability.com

www.cbd.int

\section{How to cite this article:}

Sangeetha, M., M. Gaddi Gangappa and Ramachandra Bhatta. 2020. An Insight into the Institutional Structure and Legal Framework to Implement the Nagoya Protocol on Access and Benefit Sharing (ABS). Int.J.Curr.Microbiol.App.Sci. 9(12): 2143-2150.

doi: https://doi.org/10.20546/ijcmas.2020.912.252 